\title{
Citizen Social Science for More Integrative and Effective Climate Action: A Science-Policy Perspective
}

\author{
Andrew P. Kythreotis ${ }^{1,2,3 *}$, Chrystal Mantyka-Pringle ${ }^{4,5}$, Theresa G. Mercer ${ }^{1}$, \\ Lorraine E. Whitmarsh ${ }^{2,3}$, Adam Corner ${ }^{3,6}$, Jouni Paavola ${ }^{7}$, Chris Chambers ${ }^{3}$, \\ Byron A. Miller ${ }^{8}$ and Noel Castree ${ }^{9,10}$ \\ ${ }^{1}$ School of Geography, University of Lincoln, Lincoln, United Kingdom, ${ }^{2}$ Tyndall Centre for Climate Change Research, \\ University of East Anglia, Norwich, United Kingdom, ${ }^{3}$ School of Psychology, Cardiff University, Cardiff, United Kingdom, \\ ${ }^{4}$ School of Environment and Sustainability, University of Saskatchewan, Saskatoon, SK, Canada, ${ }^{5}$ Wildlife Conservation \\ Society, Toronto, ON, Canada, ${ }^{6}$ Climate Outreach, Oxford, United Kingdom, ${ }^{7}$ School of Earth and Environment, University of \\ Leeds, Leeds, United Kingdom, ${ }^{8}$ Department of Geography, University of Calgary, Calgary, AB, Canada, ${ }^{9}$ School of \\ Environment, Education and Development, University of Manchester, Manchester, United Kingdom, ${ }^{10}$ School of Geography \\ and Sustainable Communities, University of Wollongong, Wollongong, NSW, Australia
}

OPEN ACCESS

Edited by:

Fátima Alves,

Universidade Aberta, Portugal

Reviewed by:

Rita Campos,

Universidade de Coimbra, Portugal

Christos Dimitrios Arvanitidis,

Hellenic Centre for Marine Research

(HCMR), Greece

*Correspondence:

Andrew P. Kythreotis

AKythreotis@lincoln.ac.uk

Specialty section:

This article was submitted to Interdisciplinary Climate Studies,

a section of the journal

Frontiers in Environmental Science

Received: 18 October 2018

Accepted: 16 January 2019

Published: 05 February 2019

Citation:

Kythreotis AP, Mantyka-Pringle C, Mercer TG, Whitmarsh LE, Corner A,

Paavola J, Chambers C, Miller BA and

Castree N (2019) Citizen Social

Science for More Integrative and

Effective Climate Action: A

Science-Policy Perspective

Front. Environ. Sci. 7:10.

doi: 10.3389/fenvs.2019.00010
Governments are struggling to limit global temperatures below the $2^{\circ} \mathrm{C}$ Paris target with existing climate change policy approaches. This is because conventional climate policies have been predominantly (inter)nationally top-down, which limits citizen agency in driving policy change and influencing citizen behavior. Here we propose elevating Citizen Social Science (CSS) to a new level across governments as an advanced collaborative approach of accelerating climate action and policies that moves beyond conventional citizen science and participatory approaches. Moving beyond the traditional science-policy model of the democratization of science in enabling more inclusive climate policy change, we present examples of how CSS can potentially transform citizen behavior and enable citizens to become key agents in driving climate policy change. We also discuss the barriers that could impede the implementation of CSS and offer solutions to these. In doing this, we articulate the implications of increased citizen action through CSS in moving forward the broader normative and political program of transdisciplinary and co-productive climate change research and policy.

Keywords: Citizen Social Science, climate policy and governance, science-policy, citizen agency and behavior, co-production and co-learning

\section{INTRODUCTION}

This paper examines why current forms of climate policy are not working and offers some suggestions as to how to further increase citizen engagement in science and policy decisions at different scales of governance that move beyond tokenistic forms of citizen participation. We offer a framework for what we call "citizen social science" (CSS), highlighting the various social, political and institutional barriers that prevent greater citizen participation in climate science and policy decisions. We then present some suggestions as to how CSS can potentially be used to overcome these barriers to enable citizens to contribute more effectively and directly to ambitious formal climate policy goals. 


\section{CITIZEN PARTICIPATORY ISSUES WITH CURRENT FORMS OF CLIMATE POLICY-MAKING}

National governments make top-down climate policy decisions that often involve little input from lay citizens. Consequently, when it is time for a policy to be implemented there can be public resistance to it or lack of uptake. The challenge, therefore, is not only to make climate policy more robust, but to also further democratize citizen involvement in policy formulation to increase uptake. There have been repeated calls for increased citizen engagement, understanding individual behavior, and greater channels of communication between different stakeholders in both scientific and policy discourses related to climate change that move beyond mere public acceptance of the physical evidence of climate change (Lassen et al., 2011; Beniston, 2013; Schweizer et al., 2013; Swart et al., 2014; Sörqvist, 2016; Carvalho et al., 2017; Sprain and Reinig, 2018). It is never more imperative that the forms and structures of citizen engagement in climate science and policy decisions remain central to climate action given that the Paris Agreement will afford non-state actors (e.g., private and third sector groups) more influence in formal policy implementation (Van Asselt, 2016; Kuyper et al., 2018). The latest Intergovernmental Panel on Climate Change (IPCC) Special Report (Global Warming of $1.5^{\circ} \mathrm{C}$ an IPCC special report on the impacts of global warming ${ }^{1}$ of, 3) has emphasized how the "strengthening of capacities for climate action of national and sub-national authorities, civil society, the private sector, Indigenous peoples and local communities" is key to achieving ambitious climate policy goals that will limit warming below $1.5^{\circ} \mathrm{C}$ by 2100 . But citizens and institutions must act together, now.

However, democratically legitimizing increased citizen engagement within current institutional structures is complex given how such structures demarcate lay citizens from scientific experts and/or government (Miller and Rose, 2017). Even polycentric climate governance systems that are supposed to incorporate private and third sector groups into policy decisions suffer from orchestration from particular government (state) actors, resulting in systematic governance experimentation and learning being stifled (Abbott, 2017). Furthermore, communication practices often exist between citizens, scientific experts and/or government that constrain increased citizen engagement in climate change policy formulation and implementation (Carvalho et al., 2017). Hence, the governance crisis of the sustainability paradigm continues (Peters, 2017), where states continue to dominate the international political discourse of climate change through particular modes of governmentality and sovereignty (Kythreotis, 2012; Bäckstrand and Lövbrand, 2016), ostracizing citizens within the climate policy process and thus delimiting greater citizen participation in helping achieving ambitious climate policy goals made by formal policy actors like the state.

\footnotetext{
${ }^{1}$ Available at: https://www.ipcc.ch/pdf/special-reports/sr15/ sr15_headline_statements.pdf (Accessed Oct 16, 2018).
}

Increased lay citizen participation in climate science and policy decisions can limit the influence of institutional expertise in democratic spaces that often do not speak for the majority of citizens (Sprain and Reinig, 2018). Given the limitations in citizen science translating to effective climate action (Groulx et al., 2017), we argue that increased public engagement in the "politics of science" (Jasanoff, 2003) and what we call the "politics of policy" (how policy is politicized by governments) can help protect against public misinformation on climate change, prevent particular forms of epistemic expertise dominating climate science-policy decisions, producing more transparently public-engaged climate politics and policy. In this sense, citizens can become active agents of policy change through their actions, rather than being just part of a wider normative political participatory process dominated by state policy discourses that have predominantly politicized climate science and policy (Lövbrand et al., 2015; Bäckstrand and Lövbrand, 2016).

The Paris Agreement aims for an ambitious and transformational era of international climate change policy (Kinley, 2017). However, limiting global temperatures to below $2^{\circ} \mathrm{C}$ by 2100 is governed by techno-managerial language and policy responses to fossil fuel derived energy production (Hoffert et al., 2002; Hoffmann, 2011) rather than identifying lay peoples' concerns, values and goals for their communities. Framing the climate problem in this more personal way can promote more transformational engagement and ownership in climate decision-making (Nisbet, 2009; Leach et al., 2010), especially given that some research has shown how non-specialists find it difficult to understand how physical climate risks can impact their lives (Pidgeon and Fischhoff, 2011). Failure to consider citizens' concerns undermines the legitimacy of formal climate policy decisions, limiting the ability of citizens to play a more influential role in instigating policy change through citizen action. Interdisciplinary co-produced research is needed between citizens, scientists and policymakers to span knowledge and spatial boundaries through wider citizen engagement and to produce research that speaks to its end users (Lemos et al., 2012; Kirchhoff et al., 2013; Turnhout et al., 2016; Editorial, 2018; Howarth et al., 2018). Yet, co-production has multiple meanings (Bremer and Meisch, 2017). However, for citizens to have more influential participation, they need to understand how the current science-policy process works with respect to the roles of research and policy actors. This could enable pro-environmental decisions, behavior and actions that complement the sciencepolicy process. With support from other state and non-state institutions, we argue that citizens can become transformative agents of social and policy change with respect to climate change through CSS.

New citizen-centered solutions are needed in climate politics for triggering deliberate social transformations and for providing a deeper inquiry into the structures and processes within society and science (O'Brien, 2012). Such solutions should be based upon social assemblages (Gillard et al., 2016) and citizen agency (Dodman and Mitlin, 2013), rather than overreliance on governments to catalyze transformational change. The withdrawal of the Trump administration from the Paris Agreement in June 2017 has demonstrated how individual 
nation states still hold the balance of power in determining policy outcomes for climate change (Kythreotis, 2015). Societal transformations can be addressed to some extent by "polycentric" governance where non-state actors support global policy-making by working across policy scales to redress the limitations of single scale (e.g., solely national) policies. However, national and international climate politics continues to play a dominant role in the polycentric governance systems and research has only just begun to distinguish between different types of climate governance, rather than assessing their effectiveness in complementing or replacing top-down, government dominated policy-making (Jordan et al., 2015). This all points to a need for increased citizen engagement to act as a further check and balance to formal climate policy decisions that are made in particular spaces dominated by epistemic actors like the state, scientists or even the market (e.g., fossil fuel companies). This certainly will produce a more reflexive "knowledge politics" on climate change that can help circumvent uneven spaces of climate decision-making (Mahony and Hulme, 2018).

\section{ELEVATING CITIZEN ENGAGEMENT}

Whilst there is some evidence of successful government- and market-led policy transitions toward cleaner energy and lower emissions (e.g., Obama, 2017), many citizens are left out of this process highlighting an urgent need to engage citizens more closely with framing the climate and energy debate, in addition to concentrating on private sector transitions through market forces that then shape government policy. Rather than thinking about possible economically sympathetic policy solutions for climate change originating from governments, policy-makers and/or even the market, the citizen has to take a more active social role in driving policy change and implementation for both mitigation (e.g., energy use) and adaptation (coping with climate impacts). However, doing this successfully requires greater interaction between climate researchers and citizens. This involves developing ways in which the everyday citizen can understand the way in which climate policy is constructed within and by governments through the traditional science-policy model where truth (e.g., science) speaks to power (e.g., policy choice) (Jasanoff and Wynne, 1998). Enlightening the citizen to how climate research is conducted (and why) firstly gives them an ideal platform from which to react to and then drive new government policies that could meet the speed of transitional change needed to limit global temperatures and avoid dangerous climate impacts. For example, research on climate adaptation has shown the importance of joint-problem framing and knowledge production, especially in contexts where scientific knowledgewhether social, economic, political or environmental-is limited or scarce (Swart et al., 2014; Huggel et al., 2015).

Although increased citizen engagement with climate research is not a full alternative to top-down political agreements or technological change, it can certainly catalyze the speed and ambition of the technological, social, political and economic changes required to meet collective climate commitments regarding mitigation and adaptation. Policy-makers and scientists have a duty to create local spaces where citizens can more fully participate further in related climate decision-making processes as a form of power brokerage (Pielke, 2007; Howarth et al., 2018). Yet, communicating climate research and policy to the general public has many challenges (Hollin and Pearce, 2015; Bernauer and McGrath, 2016). It is possible to perceive climate information without any values affecting it (i.e., bias is always there) (Corner et al., 2012). Greater citizen involvement in climate decisions within the more science-policy process could help ameliorate climate misinformation dominating political discourses on climate change. Recent research has shown how key scientific experts have a central role in utilizing knowledge networks within the formal science-policy process to catalyze climate adaptation action (Kettle et al., 2017), so by making their role more open to the everyday citizen, climate scientists (experts) can augment greater co-production practices between citizens, scientists and government policy-makers.

More integrative and effective climate action and policy can come about when citizens and the public are fully cognizant of the implications of their actions and behavior toward their (local) environment when presented with how both the science on climate change is generated by experts and used by policy-makers. This reduces miscommunication and confusion of climate science and creates the conditions where the relationship between citizen behavior, science and polices are fully transparent. This could trigger an inclination of citizens, scientists and policy-makers to want to foster integrative change rather than the current often benign, top-down and apolitical reactions to climate policy change as merely a government/state responsibility. Citizens can then act as political agents of change by increasing pressure on their elected representatives to help enable such policy change at higher state levels, rather than citizens just being used by policy-makers through tokenistic consultation (Carvalho et al., 2016).

\section{CITIZEN SOCIAL SCIENCE: MOVING BEYOND CITIZEN SCIENCE}

Citizen Science (CS) as a methodological tool for understanding large scale processes has burgeoned, arguably as a reaction to the use of particular forms of epistemic expertise that have traditionally and unilaterally contributed to policy decisions (Haas, 1992), rather than consideration of more diverse, but contextual knowledges and forms of social knowing (Irwin, 1995). Citizens can be utilized to obtain larger datasets that enable researchers to assist policy-making practice, democratizing expertise into more formal policy processes (Fischer, 1993). To December 2018 there are 57 active and searchable CS projects related to climate change that are listed on the Scistarter website (Scistarter, 2018). All of these projects involve citizens observing and collecting data, rather than formulating the CS research methods, analyzing and interpreting the data as a means to instigate climate policy action. By acting as volunteers, citizens are important for data collection to inform climate research (Bonney et al., 2014; Lahoz and Schneider, 2014) as a means to understand trends, causes, impacts, and responses to, climate 
change (Savo et al., 2016). Climate research, however, requires complex tools, such as models, remote sensing, and ice core and soil analyses to better inform broader policy, and such skills are often beyond the capabilities of lay citizens. Broader policy actors have attempted to further engage citizens more. For example, the United Nations Framework Convention on Climate Change (UNFCCC) Secretariat through collective nations, have recognized the potential of CS and have assisted in initiating and implementing large citizen consultations on climate change (Bedsted et al., 2015). However, there is also a need to engender links between local policy actors and the communities they serve, particularly with respect to climate adaptation (Vogel and Henstra, 2015). So, a question remains whether CS could be used more effectively to further engage different citizens and communities for more tailored local climate policy beyond crowdsourcing to obtain large(r) data sets? There is evidence of governments and municipalities working better to include traditional and local knowledge into their governance systems (Leonard et al., 2013) but more work is needed to further integrate citizen action and climate policy-making.

CS has also been traditionally classified into various types, the most relevant for this paper being Haklay's distinction below in Table 1 between: crowdsourcing (level 1), distributed intelligence (level 2), participatory science (level 3) and extreme CS (level 4) (Sui et al., 2013). Haklay's distinctions show CS as a collaborative and participatory framework that enables citizens to assist in big data collection for scientific purposes. CS therefore, has many advantages for climate mitigation and adaptation practice and policy (Larsen and Gunnarsson-Östling, 2009; Ford et al., 2016b). Yet we argue for a new platform (see level 5) whereby citizens have increased influence within conventional science-policy and participatory frameworks in shaping climate policy, alongside the necessary technical (e.g., negative emissions technology) and policy (a shift from the 'green growth' paradigm) changes that are required (Anderson, 2015).

Though the term "citizen social science" has been previously used in the literature (Purdam, 2014), the way in which it has been explained has remained confined within the paradigm of using CS to create large data sets for policy-making. We define CSS further as representing new methodological and theoretical territory that resonates with more diverse and heterogeneous forms of social knowing, values and cultures of citizens beyond CS (Castree et al., 2014). While CS uses citizens as policy passive objects for research in conducting measurements for big data sets, our proposed CSS framework makes citizens co-learners within the research process by actively enabling them to explore transformatively changing institutionalized research and policy systems. CSS embraces the principles of a "Two-Eyed Seeing" approach in an Indigenous and scientific knowledge systems context; where a co-learning journey (where citizens take a lead, often over government/policymakers, in making decisions about how best to formulate policy) is encouraged for more transdisciplinary research and to bring together different ways of knowing (Bartlett et al., 2012). One way of differentiating CSS from CS is therefore to consider this "two-eyed seeing" approach that repositions citizens as central co-learners that can widen the climate science evidence-base to a more holistic understanding of perspectives for the benefit of all. Recent research has illustrated how blending scientific and traditional knowledges through citizen co-learning highlighted key environmental stressors under uncertainty (Mantyka-Pringle et al., 2017). Hence, this demonstrates the difference between citizens getting involved in public engagement exercises within formal policy processes and apparatus, and citizens being catalysts and drivers of climate policy transformation. With public engagement, participants often work within pre-conceived state ideas and traditional governance structures that are institutionally entrenched in top-down power dynamics (e.g., a particular policy standpoint based on ideology) (Morrison et al., 2017) designed to protect the political economy status-quo. Co-production or co-learning through CSS moves beyond conventional public engagement and makes the citizens initiate action and policy responses based on their specific forms of social knowing and values. This organic form of bottom-up collaborative knowledge-making can help to eliminate any cultural issues and insensitivities that may emerge upscale when formulating policies. It can also catalyze transformative change through the eyes of everyday citizens by allowing them to be exposed to climate policy decisions that they would not normally be involved or interested in. Therefore, CSS is underpinned by multiple disciplines and methods of co-production enabling citizens to make more context specific, transparent and explicit contribution to climate policy-making and action.

\section{BARRIERS AND (POTENTIAL) SOLUTIONS TO IMPLEMENTING CSS}

While we argue that implementing CSS at a larger scale is key for achieving Paris climate commitments, there are a number of barriers to successfully implementing CSS effectively. The following is a suggested approach to begin dealing with such barriers. Working toward more integrative and effective climate change solutions between citizens and policy-makers involves developing a profound understanding of the complex interactions between those different actors with the physical, social, economic and political world that leads to decisional conflict and policy inertia over climate change. This requires changing the "decision environment" as a means to circumvent or at least ameliorate some of these institutionalized barriers (Howden et al., 2007).

\section{Reframing the Climate Change Problem}

Most citizens often feel disengaged and unable to influence policy, including climate change policy, or to significantly change their lifestyles to tackle climate change for a range of institutional, social and psychological reasons (Hoppner and Whitmarsh, 2010). As a collective problem, climate change can feel overwhelming and individuals lack self-efficacy to act (Koletsou and Mancy, 2012). Prevailing social norms to consume and lack of trust in governments or other people to take action also erodes motivation to act (Whitmarsh et al., 2010). For many, climate change (policy) also threatens assumptions about quality of life, fairness, progress and individual freedom, 
TABLE 1 | Levels of participation and engagement (adapted from Sui et al., 2013).

\begin{tabular}{|c|c|c|c|}
\hline \multirow{4}{*}{ 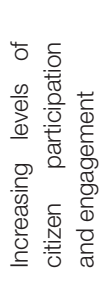 } & $\begin{array}{l}\text { (Level 5) } \\
\text { Leve- } 4\end{array}$ & "Extreme Citizen Science" & $\begin{array}{l}\text { - Citizens as key agents of research, action AND policy change at ALL levels of engagement } \\
\text { and scales of the decision-making process } \\
\text { Collaborative science-problem definition, data collection and analysis }\end{array}$ \\
\hline & Level 3 & "Participatory Science" & - Participation in problem definition and data collection \\
\hline & Level 2 & "Distributed Intelligence" & $\begin{array}{l}\text { - Citizens as basic interpreters } \\
\text { - Volunteered thinking }\end{array}$ \\
\hline & Level 1 & "Crowdsourcing" & $\begin{array}{l}\text { - Citizens as sensors } \\
\text { - Volunteered computing }\end{array}$ \\
\hline
\end{tabular}

leading to political and ideological division in responding to the issue. However, citizen engagement in policy and behavioral change is more likely to occur if issues are framed around audience values and more local and tangible concerns; and if individuals believe their actions make a difference (Whitmarsh et al., 2010). For example, at the individual level, giving people feedback on their energy use via energy displays can encourage energy conservation behavior (Darby, 2006); while acting as an organization, community or city can give people a sense of collective efficacy to address global problems like climate change (Sweetman and Whitmarsh, 2016). Framing climate change as a local issue may help engage individual citizens if they feel a sense of place attachment (Devine-Wright, 2013), although this might also undermine the perceived severity of the issue (Brügger et al., 2015). Framing climate change in terms of impacts and adaptation is less likely to threaten citizens (including those on the right-of-center) than mitigation messages, which tend to imply individual sacrifice (e.g., reducing energy use Howell et al., 2016; while other frames (e.g., reducing waste) and focusing on co-benefits of action (e.g., health, social cohesion) may also be more engaging across the political spectrum (Whitmarsh and Corner, 2017).

Reframing the problem also requires a need to reconsider the role of gender and cultural equality. Climate change is more likely to adversely impact Indigenous people and women due to their increased vulnerability (IPCC, 2014; Halton, 2018). For instance, we know that climate change is having disproportionate effects on the human health of Indigenous people globally (Green et al., 2009; Ford et al., 2010). Calls have also been made for better representation of Indigenous knowledge and Indigenous issues in IPCC assessments and other global climate policy (MantykaPringle et al., 2015; Ford et al., 2016a,c). There are obvious gender differences in environmental concerns and attitudes and impacts (McCright, 2010), particularly in developing countries. For example, two-thirds of the female labor force dependent on agricultural work in developing countries are adversely affected by poor harvest, which leads to food, income and health security issues (UN WomenWatch Women, 2018). To address the current imbalances, more cultural and gender sensitive responses are required to create the social and political conditions needed to address climate-related problems. The most obvious way to catalyze equality is by creating scientific and policy pathways that enable increased involvement of Indigenous people and women in the science-policy realm. This needs to be addressed from the local to international scale (Gay-Antaki and Liverman, 2018). The values innate to CSS promotes gender and cultural equality in climate change by providing an inclusive and integrative framework by which women and Indigenous people are supported to engage with climate research, policy and taking relevant action. However, there needs to be a degree of top-down support from the science-policy realm to normalize such local gender and cultural equality in climate decisions through CSS. If scientific and policy expert communities do not reflect on gender and cultural imbalances, then how would we expect women and Indigenous citizens to take a lead on climate action in their own communities through CSS? If this two-way process is facilitated, financially supported, and mainstreamed then there would be a greater chance of women and Indigenous citizens being more empowered to transformatively act on their own behalf through CSS (Alston, 2014).

Transformative responses through CSS do not assume a particular scientific approach and therefore must begin with a discussion of participants' values, based on their moral, aesthetic, experiential, spiritual knowledge concerns and aspirations rather than policy being solely foisted upon citizens in a topdown way. Yet there must be a heterogeneity of climate responses from all areas of society-governments, scientists and citizens who have been previously apathetic to climate change. This process leads to a recognition that there are communal values held by citizens that can serve as a bridge toward an overarching global climate policy goal, like the $2^{\circ} \mathrm{C}$ Paris target. Discussions about fears and hopes for the future can provide a "lens" through which to discuss climate change research and to explore different narratives and pathways for public engagement that move beyond current techno-managerial and gender imbalanced sciencepolicy approaches.

\section{Conflicts of Interest}

Whilst we recognize that conflicts of interest will endure between different stakeholders in making appropriate climate decisions, it is nevertheless omnipresent in the current climate sciencepolicy process. There are a number of existing groups of citizens with conflicts of interest related to climate change science. The most obvious are climate deniers and citizens that benefit from or are dependent on the fossil fuel industry for their livelihood. It is possible that these groups may choose to be involved in CSS to impose their views or advance their standpoint to reaching their political objectives such as undermining or misrepresenting the science behind climate change (Editorial, 2015). In the application of CS, it has been reported that there remain limitations in CS enabling local climate actions (Groulx 
et al., 2017). These types of conflicts of interest may also be experienced in CSS and need to be taken into account or at the very least acknowledged so that the process will not be skewed in favor of one standpoint, and therefore remain representative. However, we are cognizant that any policy decisions should not be taken on the basis of the equal representation of all views (as some views are obviously extreme in ideology, anarchic and/or reject observed scientific facts) but on the basis of the scientific knowledge which solves or mitigates the real problem.

Less obvious conflicts of interest also exist in some cultural contexts (e.g., different ways of understanding and valuing the environment), inequality (e.g., class) and ethno-national diversity conflicts (e.g., land ownership conflicts with Indigenous vs. nonIndigenous groups). A potential solution is to ensure that there is a representative sample of the population in the process and citizens' backgrounds are respectfully vetted beforehand. Where there are conflicts of interest between people, the process of CSS acts as a mediation channel to bridge polarized views through a common purpose. It enables new narratives to be explored as different viewpoints are represented and considered within the co-production environment.

\section{CSS Cannot be Implemented as a "One Size Fits All" Knowledge Framework}

We are cognizant that CSS can only work if the knowledge domain of citizens is germane to their everyday life. For example, rural farmers should not find themselves working or co-researching on urban transport issues and urban citizens should not find themselves working on agricultural issues unless they hold real knowledge in that area to enable more effective action and policy. Apart from the intimate knowledge that some citizens have with their natural surroundings (e.g., Indigenous traditional knowledge), much of modern life involves epistemic dependence on trained experts. The limits of lay knowledge (and particularly lay expertise) in matters of climate change are therefore restricted (Dunlap and McCright, 2015). Low carbon housing and civil engineering projects are classic examples because the majority of citizens are users of pre-made structures they could not design without being trained in engineering science. So there is a caveat about how far CSS can extend in a "rule of experts" context. The uniqueness of the CSS framework is within the way in which infrastructure is used through our behavioral patterns, which is predicated upon how citizens make sense of different forms of knowledges to inform their actions as a means to make real transformative change. Greater government acceptance of citizen potential is needed to quell those hidden assumptions of people not mattering, or not being educated enough to make informed decisions. CSS can expose and ameliorate these hidden assumptions. This is where allying of citizens with knowledge-brokers plays a significant role. The Climate Knowledge Brokers Group (Climate Knowledge Brokers, 2017) is an excellent example of how citizens can get further involved in understanding the causes and consequences of climatic change and to create a focal point for diverse citizen voices to be heard regarding climate change. In this sense there is a need to move beyond scientists merely having to consider the types of idealized roles they have to play in public policy and politics beyond the science-policy process (Pielke, 2007). Scientists and experts have to consider what role they can play in more openly engaging with citizens as a means to help citizens determine the types of knowledge that can inform policy decisions made by government (and vice versa). This will then more democratically legitimize citizen involvement in policy-making by placing citizens at the center of new policy formulations, rather than politicizing the role of science and scientists in public policy and politics.

\section{Uneven Power Relationships}

Making citizens more central within the science-policy process is inevitably constrained by pre-existing uneven power relationships between politicians and citizens, scientists and citizens, and scientists and politicians. These silo relationships are often defined through different vested interests, rigid funding and reporting structures, lack of communication skills among researchers and their (subconscious) beliefs about the lack of skills and critical awareness of "the masses" (Burgess et al., 2017). The barriers to greater citizen involvement because of lack of voice, visibility or opportunity are often formidable and there needs to be more active integration between lay citizens, climate researchers and policy-makers. Currently, important political arenas for climate policy decisions like UNFCCC Conference of the Parties have been dominated by national governments and closed-off to the lay citizen. While lay citizens often (rightfully) demonstrate at such climate negotiations, there remains a physical and political barrier between where state-led political decisions are made and the equitable and just contribution that citizens should make to the climate change political process, as recent research on the Paris Conference of the Parties has shown (Weisser and Müller-Mahn, 2016).

Uneven power relationships also exist between scientists and citizens. Scientists are constrained by how they can approach their research methodology and data collection based on rigid reporting structures of their institutions and funding bodies. Although research bodies such as Research Councils UK and the National Science Foundation (US) now require research projects to demonstrate the impact of their work to beneficiaries outside of academia (RCUK, 2014; NSF, 2018) and data/publications of their research as Open Access (NSF, 2015; RCUK, 2017), there are no specific requirements to involve citizens directly in the coproduction of research (even though we are cognizant that more theoretical science may not require co-production research with citizens). However, climate research certainly does given that the anthropogenic climate change problem can be reduced to human behavior (Karl and Trenberth, 2003). Additionally, scientists' biases have been demonstrated in citizen science projects where certain data sources are favored over others (e.g., based on the background/education level of the data collectors). This suggests a belief that citizens do not possess the necessary knowledge or data collection skills to perform robust science to the standards of scientific "experts" (Burgess et al., 2017).

There are also uneven power relationships between scientists and governments. Notwithstanding the systemic problem of 
not enough research professionals and academics being able to work with government regardless of discipline to engender evidence-based policy (Lawrence et al., 2016), with respect to climate change research, many of the broader science-policy arenas in which scientists can contribute to climate action and/or policy-making (albeit in a policy-neutral way) like in the IPCC Assessment Reports, continues to be tainted with a "closed club" syndrome for many academics (Shackley, 1997; Hulme and Mahony, 2010), a pronounced gender imbalance in IPCC membership (Gay-Antaki and Liverman, 2018), and scientist contributions to Summary for Policy-makers (SPM) reports have to go through a final review of government approval of the SPM line (IPCC, 2015). Equally important, certain academics continue to be ostracized in IPCC decisions and processes where the impacts of climate change are felt most (e.g., developing countries) leading to a science-policy information deficit and institutionalized epistemic communities, even though there have been attempts to make the IPCC more "user-friendly" (Petersen et al., 2015; Corbera et al., 2016).

More resources and institutional support are essential to help engage citizens in bottom-up processes that complement and inspire change through existing research and political institutions. CSS needs to be achieved through strategies targeted to different value systems that are not typically related to climate change like biospheric ones (Howell and Allen, 2017). This will have positive economic and social spillover effects beyond environmental benefits, especially in vulnerable communities (e.g., added skills and cash incentives). Governments stand to gain from increased citizen engagement in research in times of austerity (Dickinson et al., 2012) and the private sector can enhance their corporate social responsibility by supporting employees in CSS projects. There is a need to move climate research toward a more collaborative role in which it is co-produced by citizens, industry, decision-makers and scientists so that the research has stronger outreach and generates more effective policies (Pearce et al., 2009). But which sectors are best placed to catalyze CSS projects? The public, private and/or third sectors? A possible starting point we argue is that maybe universities are best placed to initiate and facilitate such CSS projects. They are not so much impartial as designed, in principle, to serve the interests of publics. Rather, they provide a range of knowledge and invention that pluralizes options and speaks to an array of cognitive, moral, aesthetic and spiritual positions existing in the world. Research has shown that those with a higher education share more cultural commonalities over global climate change (Crona et al., 2013). Whilst we are aware of the new instrumentalism in universities linked to business and government control, we feel universities could be best placed to initiate and facilitate CSS in comparison to the private, public and/or third sectors.

\section{Differences Across and Within Countries (scale)}

The deployment of CSS will face varied challenges across different countries and within the scalar jurisdictions of each country. CSS is plausibly easier to deploy in democratic political systems that have a commitment and track record of fostering public participation in environmental and other areas of decision-making. For example, commitments to broad principles supporting the CSS deployment have been made under the Aarhus Convention of 1998 and in the European Union Directives on Public Participation (2003/35/EC) and Access to Environmental Information (2003/4/EC) as well as many other more specific directives such as the Water Framework Directive (2000/60/EC). However, the prospects of CSS deployment are less obvious in non-democratic countries where political leadership is not representative or accountable, public participation is not legitimate or encouraged, and where political freedoms are curtailed, and civil society organizations do not welcome freedom of speech.

There are also challenges for CSS within countries at different scalar jurisdictions depending on the system of government and the various powers attributed to government at different jurisdictional scales. Levels of political autonomy and a willingness to embrace more networked and polycentric governance with respect to climate change can result in a failure of knowledge upscaling if citizens are not equipped to deal with the "politics of scale." This especially comes into play when citizens with only their local experience(s) are asked to speak as "researchers" on national or global issues. But CSS would not exclude these diverse knowledges, but rather warn cautiousness during implementation and acknowledge that there are caveats about how far CSS can extend in a "rule of experts" context across different spatial jurisdictions. This has been acknowledged in the literature regarding the problems of political power and scale when trying to implement more networked forms of climate governance (Morrison et al., 2017) through social knowing.

One possible solution is to give local citizens greater participatory influence in local processes of governance and policy-making and forming stronger links between communities and local policy-makers. For making local climate decisions, one example could be to employ an opinion poll company to choose the citizens to participate in local consultation processes, much like is done with citizen juries. By providing selected citizens with knowledge on climate research and how policy is constructed, citizens become more actively engaged in policy and can deliberate the type of policies to be utilized by local/national governments through "mini publics." This has proved successful in Ireland, where a nationwide exercise in deliberative democracy demonstrated that citizens with limited initial knowledge become "enlightened" (Suiter et al., 2016) and more likely to change their minds on salient issues based on the best available evidence. Other novel ways of eliciting public opinion and engaging them include citizen awards/incentives for new ideas that promote climate action within the community, and citizen draws that allow citizens time off work to volunteer in local and state council meetings related to climate change (similar to jury duty, but without the legal powers). With citizens enjoying a more central role in helping to determine formal policy, government still has an important enabling role to play by investing more in financial and human resources. This can then more clearly align the roles that citizens and government authorities play 
in the policy process, promoting a more transparent bottomup approach to climate-related co-planning issues (Mees et al., 2017). This further bridges the gap between how climate change is governed by citizens, governments and the market across international, national and local jurisdictions. Particularly at the local scale though, CSS could provide more active engagement by bringing citizens into the pre-consultation phase during policy development, rather than citizens just being used in a tokenistic way within the initial stages of policy planning by governments.

\section{CONCLUSION}

This paper has examined how CSS can offer a fruitful way of contributing to more integrative and effective climate action and policy that moves beyond the traditional science-policy model. We have discussed a framework for CSS followed by potential barriers and solutions. With respect to the barriers mentioned above, a sub-set of citizens and policy-makers across the board will have to work hard to create arenas where existing power asymmetries can be suspended through institutions, venues and gatherings that permit a rough "communicative equality."

We argue that the barriers to CSS are not insurmountable and CSS can truly catalyze transformative change if citizens and policy-makers can become more aligned through processes of social knowing, especially at the local scale. By breaking down the tension between expertise and lay knowledge, experts and citizens can collaboratively explore alternative social contexts outside of

\section{REFERENCES}

Abbott, K. W. (2017). Orchestration : strategic ordering in polycentric climate governance. SSRN Electron. J. 30. doi: 10.13140/RG.2.2.10435. 60962

Alston, M. (2014). Gender mainstreaming and climate change. Womens Stud. Int. Forum 47, 287-294. doi: 10.1016/j.wsif.2013.01.016

Anderson, K. (2015). Duality in climate science. Nat. Geosci. 8, 898-900. doi: $10.1038 /$ ngeo 2559

Bäckstrand, K., and Lövbrand, E. (2016). The road to paris: contending climate governance discourses in the post-copenhagen era. J. Environ. Policy Plan. 1-19. doi: 10.1080/1523908X.2016.1150777

Bartlett, C., Marshall, M., and Marshall, A. (2012). Two-Eyed Seeing and other lessons learned within a co-learning journey of bringing together indigenous and mainstream knowledges and ways of knowing. J. Environ. Stud. Sci. 2, 331-340. doi: 10.1007/s13412-012-0086-8

Bedsted, B., Mathieu, Y., and Leyrit, C. (2015). World Wide Views on Climate and Energy. Available online at: http://climateandenergy.wwviews.org/wp-content/ uploads/2015/09/WWviews-Result-Report_english_low.pdf.

Beniston, M. (2013). Grand challenges in climate research. Front. Environ. Sci. 1:1. doi: 10.3389/fenvs.2013.00001

Bernauer, T., and McGrath, L. F. (2016). Simple reframing unlikely to boost public support for climate policy. Nat. Clim. Chang 6, 680-683. doi: $10.1038 /$ nclimate 2948

Blue, G. (2015). Public deliberation with climate change: opening up or closing down policy options? Rev. Eur. Comp. Int. Environ. Law 24, 152-159. doi: $10.1111 /$ reel.12122

Bonney, R., Shirk, J. L., Phillips, T. B., Wiggins, A., Ballard, H. L., Miller-Rushing, A. J., et al. (2014). Citizen science. Next steps for citizen science. Science 343, 1436-1437. doi: 10.1126/science. 1251554

Bremer, S., and Meisch, S. (2017). Co-production in climate change research: reviewing different perspectives. Wiley Interdiscip. Rev. Clim. Chang 8:e482. doi: $10.1002 /$ wcc. 482 traditional science (Blue, 2015). This could then catalyze the coproduction of alternative policies between citizens, scientists and policy-makers that address emerging climate issues in specific communities. Bridging citizens, scientists and governments through a CSS narrative framework that increases recognition of human qualities and needs would help reconfigure formal climate policy-making through the democratic systems already in place. Taking this transformative pathway places greater responsibility for tackling climate change in the hands of citizens, consistent with the principles of democratic governance and democratic legitimacy. However, governments, the private sector, the IPCC, and the UNFCCC still have critically important roles in helping facilitate this citizen transformation.

\section{AUTHOR CONTRIBUTIONS}

AK initiated the core idea of citizen social science and led in writing the paper with extensive development and input from CM-P, TM, NC, LW, AC, JP, CC, and BM. All authors contributed to the theoretical and conceptual development of the paper.

\section{FUNDING}

AK thanks the Regional Studies Association for an early career research grant that initiated the development of the idea of Citizen Social Science. CM-P was supported by a Mitacs Elevate Fellowship funded by Ducks Unlimited, the Global Institute of Water Security, and Environment and Climate Change Canada.

Brügger, A., Morton, T. A., and Dessai, S. (2015). Hand in hand: public endorsement of climate change mitigation and adaptation. PLOS ONE 10:e0124843. doi: 10.1371/journal.pone.0124843

Burgess, H. K., DeBey, L. B., Froehlich, H. E., Schmidt, N., Theobald, E. J., Ettinger, A. K., et al. (2017). The science of citizen science: exploring barriers to use as a primary research tool. Biol. Conserv. 208, 113-120. doi: 10.1016/J.BIOCON.2016.05.014

Carvalho, A., Pinto-Coelho, Z., and Seixas, E. (2016). Listening to the publicenacting power: citizen access, standing and influence in public participation discourses. J. Environ. Policy Plan. 1-19. doi: 10.1080/1523908X.2016.1149772

Carvalho, A., van Wessel, M., and Maeseele, P. (2017). Communication practices and political engagement with climate change: a research agenda. Environ. Commun. 11, 122-135. doi: 10.1080/17524032.2016.1241815

Castree, N., Adams, W. M., Barry, J., Brockington, D., Büscher, B., Corbera, E., et al. (2014). Changing the intellectual climate. Nat. Clim. Chang 4, 763-768. doi: $10.1038 /$ nclimate2339

Climate Knowledge Brokers (2017). What is the CKB Group? Available online at: http://www.climateknowledgebrokers.net/what-is-ckb/ (Accessed Nov 10, 2017).

Corbera, E., Calvet-Mir, L., Hughes, H., and Paterson, M. (2016). Patterns of authorship in the IPCC Working Group III report. Nat. Clim. Chang 6, 94-99. doi: $10.1038 /$ nclimate 2782

Corner, A., Whitmarsh, L., and Xenias, D. (2012). Uncertainty, scepticism and attitudes towards climate change: biased assimilation and attitude polarisation. Clim. Change 114, 463-478. doi: 10.1007/s10584-012-0424-6

Crona, B., Wutich, A., Brewis, A., and Gartin, M. (2013). Perceptions of climate change: linking local and global perceptions through a cultural knowledge approach. Clim. Change 119, 519-531. doi: 10.1007/s10584-013-0708-5

Darby, S. (2006). Social learning and public policy: Lessons from an energy-conscious village. Energy Policy 34, 2929-2940. doi: 10.1016/j.enpol.2005.04.013

Devine-Wright, P. (2013). Think global, act local? The relevance of place attachments and place identities in a climate changed world. 
Glob. Environ. Chang. 23, 61-69. doi: 10.1016/j.gloenvcha.2012. 08.003

Dickinson, J. L., Shirk, J., Bonter, D., Bonney, R., Crain, R. L., Martin, J., et al. (2012). The current state of citizen science as a tool for ecological research and public engagement. Front. Ecol. Environ. 10, 291-297. doi: 10.1890/110236

Dodman, D., and Mitlin, D. (2013). Challenges for community-based adaptation: discovering the potential for transformation. J. Int. Dev. 25, 640-659. doi: $10.1002 /$ jid. 1772

Dunlap, R. E., and McCright, A. M. (2015). "Challenging climate change: the denial countermovement," in Climate Change and Society: Sociological Perspectives, eds R. E. Dunlap and R. J. Brulle (New York, NY: Oxford University Press), 480.

Editorial (2015). Rise of the citizen scientist. Nature 524, 265. doi: 10.1038/524265a

Editorial, N. (2018). The best research is produced when researchers and communities work together. Nature 562, 7-7. doi: $10.1038 / \mathrm{d} 41586-018-06855-7$

Fischer, F. (1993). Citizen participation and the democratization of policy expertise: from theoretical inquiry to practical cases. Policy Sci. 26, 165-187. doi: 10.1007/BF00999715

Ford, J., Maillet, M., Pouliot, V., Meredith, T., Cavanaugh, A., Lwasa, S., et al. (2016c). Adaptation and indigenous peoples in the United Nations Framework Convention on Climate Change. Clim. Change 139, 429-443. doi: 10.1007/s10584-016-1820-0

Ford, J. D., Berrang-Ford, L., King, M., and Furgal, C. (2010). Vulnerability of Aboriginal health systems in Canada to climate change. Glob. Environ. Chang. 20, 668-680. doi: 10.1016/j.gloenvcha.2010.05.003

Ford, J. D., Cameron, L., Rubis, J., Maillet, M., Nakashima, D., Willox, A. C., et al. (2016a). Including indigenous knowledge and experience in IPCC assessment reports. Nat. Clim. Chang 6, 349-353. doi: 10.1038/nclimate2954

Ford, J. D., Tilleard, S. E., Berrang-Ford, L., Araos, M., Biesbroek, R., Lesnikowski, A. C., et al. (2016b). Opinion: big data has big potential for applications to climate change adaptation. Proc. Natl. Acad. Sci. U.S.A. 113, 10729-10732. doi: $10.1073 /$ pnas. 1614023113

Gay-Antaki, M., and Liverman, D. (2018). Climate for women in climate science: women scientists and the intergovernmental panel on climate change. Proc. Natl. Acad. Sci. U.S.A. 115, 201710271. doi: 10.1073/pnas.1710271115

Gillard, R., Gouldson, A., Paavola, J., and Van Alstine, J. (2016). Transformational responses to climate change: beyond a systems perspective of social change in mitigation and adaptation. Wiley Interdiscip. Rev. Clim. Chang 7, 251-265. doi: $10.1002 /$ wcc. 384

Green, D., King, U., and Morrison, J. (2009). Disproportionate burdens: the multidimensional impacts of climate change on the health of Indigenous Australians. Med. J. Aust. 190, 4-5. doi: 10.5694/j.1326-5377.2009.tb02250.x

Groulx, M., Brisbois, M. C., Lemieux, C. J., Winegardner, A., and Fishback, L. A. (2017). A role for nature-based citizen science in promoting individual and collective climate change action? A Systematic Review of Learning Outcomes. Sci. Commun. 39, 45-76. doi: 10.1177/1075547016688324

Haas, P. M. (1992). Introduction: epistemic communities and international policy coordination. Int. Organ. 46, 1. doi: 10.1017/S0020818300001442

Halton, M. (2018). Climate Change "impacts Women More Than Men"-BBC News. Available online at: http://www.bbc.com/news/science-environment- 43294221 (Accessed Mar 10, 2018).

Hoffert, M. I., Caldeira, K., Benford, G., Criswell, D. R., Green, C., Herzog, H., et al. (2002). Advanced technology paths to global climate stability: energy for a greenhouse planet. Science 298, 981-987. doi: 10.1126/science.1072357

Hoffmann, M. J. (2011). Climate Governance at the Crossroads: Experimenting With a Global Response After Kyoto. Oxford: Oxford University Press. Available online atat: https://books.google.com/books?hl=en\&lr=\&id=8sOnHfu69GgC\& pgis $=1$ (Accessed May 17, 2016)

Hollin, G. J. S., and Pearce, W. (2015). Tension between scientific certainty and meaning complicates communication of IPCC reports. Nat. Clim. Chang 5, 753-756. doi: 10.1038/nclimate2672

Hoppner, C., and Whitmarsh, L. (2010). "Public engagement in climate action: policy and public expectations," in Engaging the Public with Climate Change: Behaviour Change and Communication, eds L. Whitmarsh, S. O'Neill, and I. Lorenzoni (London: Earthscan), 47-65.

Howarth, C., Morse-Jones, S., Brooks, K., and Kythreotis, A. (2018). Co-producing UK climate change adaptation policy: an analysis of the 2012 and 2017 UK Climate Change Risk Assessments. Environ. Sci. Policy 89, 412-420. doi: 10.1016/j.envsci.2018.09.010
Howden, S. M., Soussana, J.-F., Tubiello, F. N., Chhetri, N., Dunlop, M., and Meinke, H. (2007). Adapting agriculture to climate change. Proc. Natl. Acad. Sci.U.S.A. 104, 19691-19696. doi: 10.1073/pnas.0701890104

Howell, R., and Allen, S. (2017). People and planet: values, motivations and formative influences of individuals acting to mitigate climate change. Environ. Values 26, 131-155. doi: 10.3197/096327117X14847335385436

Howell, R., Capstick, S., and Whitmarsh, L. (2016). Impacts of adaptation and responsibility framings on attitudes towards climate change mitigation. Clim. Change 136, 445-461. doi: 10.1007/s10584-016-1627-Z

Huggel, C., Scheel, M., Albrecht, F., Andres, N., Calanca, P., Jurt, C., et al. (2015). A framework for the science contribution in climate adaptation: experiences from science-policy processes in the Andes. Environ. Sci. Policy 47, 80-94. doi: 10.1016/j.envsci.2014.11.007

Hulme, M., and Mahony, M. (2010). Climate change: What do we know about the IPCC? Prog. Phys. Geogr. 34, 705-718. doi: 10.1177/0309133310373719

IPCC (2014). "Climate Change 2014: Impacts, Adaptation, and Vulnerability," in Part A: Global and Sectoral Aspects. Contribution of Working Group II to the Fifth Assessment Report of the Intergovernmental Panel on Climate Change (Cambridge, UK; New York, NY).

IPCC (2015). IPCC Factsheet: How Does the IPCC Review Process Work? Available online at: https://www.ipcc.ch/site/assets/uploads/sites/2/2018/07/ sr15 headline statements.pdf (Accessed Jan 31, 2018)

Irwin, A. (1995). Citizen Science : A Study Of People, Expertise, and Sustainable Development. London; New York, NY: Routledge.

Jasanoff, S. (2003). Technologies of humility: citizen participation in governing science. Minerva 41, 223-244. doi: 10.1023/A:1025557512320

Jasanoff, S., and Wynne, B. (1998). "Science and decisionmaking. Human choice and climate change," in Human Choice and Climate Change 1: The Societal Framework, eds S. Rayner and E. L. Malone (Colombus, OH: Batelle Press), $1-87$.

Jordan, A. J., Huitema, D., Hildén, M., van Asselt, H., Rayner, T. J., Schoenefeld, J., et al. (2015). Emergence of polycentric climate governance and its future prospects. Nat. Clim. Chang 5, 977-982. doi: 10.1038/nclimate2725

Karl, T. R., and Trenberth, K. E. (2003). Modern global climate change. Science 302, 1719-1723. doi: 10.1126/science. 1090228

Kettle, N. P., Trainor, S. F., and Loring, P. A. (2017). Conceptualizing the sciencepractice interface: lessons from a collaborative network on the front-line of climate change. Front. Environ. Sci. 5:33. doi: 10.3389/fenvs.2017.00033

Kinley, R. (2017). Climate change after Paris: from turning point to transformation. Climate Policy 17, 9-15. doi: 10.1080/14693062.2016.1191009

Kirchhoff, C. J., Carmen Lemos, M., and Dessai, S. (2013). Actionable knowledge for environmental decision making: broadening the usability of climate science. Annu. Rev. Environ. Resour. 38, 393-414. doi: 10.1146/annurev-environ-022112-112828

Koletsou, A., and Mancy, R. (2012). Which efficacy constructs for large-scale social dilemma problems? Individual and collective forms of/nefficacy and outcome expectancies in the context of climate change mitigation. Risk Manag. Spec. issue'Risk, Environ. Sustain. 13, 184-208. doi: 10.2307/41407073

Kuyper, J. W., Linnér, B. O., and Schroeder, H. (2018). Non-state actors in hybrid global climate governance: justice, legitimacy, and effectiveness in a post-Paris era. Wiley Interdiscip. Rev. Clim. Chang. 9:e497. doi: 10.1002/wcc.497

Kythreotis, A. (2012). Progress in global climate change politics? Reasserting national state territoriality in a 'post-political' world. Prog. Hum. Geogr. 36, 457-474. doi: 10.1177/0309132511427961

Kythreotis, A. (2015). Carbon pledges: alliances and ambitions. Nat. Clim. Chang. 5, 806-807. doi: 10.1038/nclimate 2764

Lahoz, W. A., and Schneider, P. (2014). Data assimilation: making sense of earth observation. Front. Environ. Sci. 2:16. doi: 10.3389/fenvs.2014.00016

Larsen, K., and Gunnarsson-Östling, U. (2009). Climate change scenarios and citizen-participation: Mitigation and adaptation perspectives in constructing sustainable futures. Habitat Int. 33, 260-266. doi: 10.1016/j.habitatint.2008.10.007

Lassen, I., Horsbøl, A., Bonnen, K., and Pedersen, A. G. J. (2011). Climate change discourses and citizen participation: a case study of the discursive construction of citizenship in two public events. Environ. Commun. 5, 411-427. doi: 10.1080/17524032.2011.610809

Lawrence, N., Chambers, G., Morrison, S., O'Grady, G., Chambers, C., and Kythreotis, A. (2016). The evidence information service as a new platform for supporting evidence-based policy: a consultation of UK parliamentarians. Evid. Policy 13, 275-316. doi: 10.1332/174426416X14643531912169 
Leach, M., Scoones, I., and Stirling, A. (2010). Governing epidemics in an age of complexity: narratives, politics and pathways to sustainability. Glob. Environ. Chang 20, 369-377. doi: 10.1016/j.gloenvcha.2009.11.008

Lemos, M. C., Kirchhoff, C. J., and Ramprasad, V. (2012). Narrowing the climate information usability gap. Nat. Clim. Chang 2, 789-794. doi: $10.1038 /$ nclimate1614

Leonard, S., Parsons, M., Olawsky, K., and Kofod, F. (2013). The role of culture and traditional knowledge in climate change adaptation: insights from East Kimberley, Australia. Glob. Environ. Chang 23, 623-632. doi: 10.1016/j.gloenvcha.2013.02.012

Lövbrand, E., Beck, S., Chilvers, J., Forsyth, T., Hedrén, J., Hulme, M., et al. (2015). Who speaks for the future of Earth? How critical social science can extend the conversation on the Anthropocene. Glob. Environ. Chang 32, 211-218. doi: 10.1016/j.gloenvcha.2015.03.012

Mahony, M., and Hulme, M. (2018). Epistemic geographies of climate change: science, space and politics. Prog. Hum. Geogr. 42, 395-424. doi: $10.1177 / 0309132516681485$

Mantyka-Pringle, C. S., Jardine, T. D., Bradford, L., Bharadwaj, L., Kythreotis, A., Fresque-Baxter, J., et al. (2017). Bridging science and traditional knowledge to assess cumulative impacts of stressors on ecosystem health. Environ. Int. 102, 125-137. doi: 10.1016/j.envint.2017.02.008

Mantyka-Pringle, C. S., Westman, C. N., Kythreotis, A., and Schindler, D. W. (2015). Honouring indigenous treaty rights for climate justice. Nat. Clim. Chang 5, 798-801. doi: 10.1038/nclimate2714

McCright, A. M. (2010). The effects of gender on climate change knowledge and concern in the American public. Popul. Environ. 32, 66-87. doi: 10.1007/s11111-010-0113-1

Mees, H., Crabbé, A., and Driessen, P. P. J. (2017). Conditions for citizen co-production in a resilient, efficient and legitimate flood risk governance arrangement. A tentative framework. J. Environ. Policy Plan. 19, 827-842. doi: 10.1080/1523908X.2017.1299623

Miller, P., and Rose, N. (2017). "Political power beyond the State: problematics of government," in Foucault and Law, ed P. Fitzpatrick (London: Routledge), 191-224. doi: 10.4324/9781315094021-9

Morrison, T. H., Adger, W. N., Brown, K., Lemos, M. C., Huitema, D., and Hughes, T. P. (2017). Mitigation and adaptation in polycentric systems: sources of power in the pursuit of collective goals. Wiley Interdiscip. Rev. Clim. Chang. 8:e479. doi: $10.1002 /$ wcc. 479

Nisbet, M. C. (2009). Communicating climate change: why frames matter for public engagement. Environ. Sci. Policy Sustain. Dev. 51, 12-23. doi: 10.3200/ENVT.51.2.12-23

NSF (2015). Public Access Plan: Today's Data, Tomorrow's Discoveries: Increasing Access to the Results of Research Funded by the National Science Foundation (nsf15052). Available online at: https://www.nsf.gov/pubs/2015/nsf15052/ nsf15052.pdf (Accessed Jan 31, 2018).

NSF (2018). NSF Broader Impacts|NSF National Science Foundation. Available online at: https://www.nsf.gov/od/oia/special/broaderimpacts/ (Accessed Jan $31,2018)$.

Obama, B. (2017). The irreversible momentum of clean energy. Science 13, 126-129. doi: 10.1126/science.aam6284

O'Brien, K. (2012). Global environmental change II: from adaptation to deliberate transformation. Prog. Hum. Geogr. 36, 667-676. doi: 10.1177/0309132511425767

Pearce, T. D., Ford, J. D., Laidler, G. J., Smit, B., Duerden, F., Allarut, M., et al. (2009). Community collaboration and climate change research in the Canadian Arctic. Polar Res. 28, 10-27. doi: 10.1111/j.1751-8369.2008.00094.x

Peters, M. (2017). Can democracy solve the sustainability crisis? Green politics, grassroots participation and the failure of the sustainability paradigm. Educ. Philos. Theory. 1-9. doi: 10.1080/00131857.2017.1388657

Petersen, A., Blackstock, J., and Morisetti, N. (2015). New leadership for a userfriendly IPCC. Nat. Clim. Chang 5, 909-911. doi: 10.1038/nclimate2766

Pidgeon, N., and Fischhoff, B. (2011). The role of social and decision sciences in communicating uncertain climate risks. Nat. Clim. Chang 1, 35-41. doi: $10.1038 /$ nclimate 1080

Pielke, R. A. (2007). The Honest Broker : Making Sense of Science in Policy and Politics. Cambridge University Press.

Purdam, K. (2014). Citizen social science and citizen data? Methodological and ethical challenges for social research. Curr. Sociol. 62, 374-392. doi: $10.1177 / 0011392114527997$
RCUK (2014). Pathways to Impact. Available online at: http://www.rcuk.ac.uk/ innovation/impacts/ (Accessed Jan 6, 2015).

RCUK (2017). RCUK Policy on Open Access-Research Councils UK. Available online at: http://www.rcuk.ac.uk/research/openaccess/policy/ (Accessed Jan 31, 2018).

Savo, V., Lepofsky, D., Benner, J. P., Kohfeld, K. E., Bailey, J., and Lertzman, K. (2016). Observations of climate change among subsistenceoriented communities around the world. Nat. Clim. Chang. 6, 462-473. doi: 10.1038/nclimate2958

Schweizer, S., Davis, S., and Thompson, J. L. (2013). Changing the conversation about climate change: a theoretical framework for place-based climate change engagement. Environ. Commun. 7, 42-62. doi: 10.1080/17524032.2012.753634

Scistarter (2018). Project finder results for climate change on SciStarter. Available online at: https://scistarter.com/finder?phrase $=$ climate $\$+\$$ change (Accessed Dec 10, 2018).

Shackley, S. (1997). The intergovernmental panal on climate change: consensual knowledge and global politics. Glob. Environ. Chang 7, 77-79. doi: 10.1016/S0959-3780(96)00035-0

Sörqvist, P. (2016). Grand challenges in environmental psychology. Front. Psychol. 7:583. doi: 10.3389/fpsyg.2016.00583

Sprain, L., and Reinig, L. (2018). Citizens speaking as experts: expertise discourse in deliberative forums. Environ. Commun. 12, 357-369. doi: 10.1080/17524032.2017.1394894

Sui, D., Elwood, S., and Goodchild, M. (eds.). (2013). Crowdsourcing Geographic Knowledge: Volunteered Geographic Information (VGI) in Theory and Practice. Dordrecht: Springer.

Suiter, J., Farrell, D. M., and O’Malley, E. (2016). When do deliberative citizens change their opinions? Evidence from the Irish Citizens' Assembly. Int. Polit. Sci. Rev. 37, 198-212. doi: 10.1177/0192512114544068

Swart, R., Biesbroek, R., and LourenÃ§o, T. C. (2014). Science of adaptation to climate change and science for adaptation. Front. Environ. Sci. 2:29. doi: 10.3389/fenvs.2014.00029

Sweetman, J., and Whitmarsh, L. (2016). Climate Justice: high-status ingroup social models increase pro-environmental action through making actions seem more moral. Top. Cogn. Sci. 8, 196-221. doi: 10.1111/tops.12178

Turnhout, E., Dewulf, A., and Hulme, M. (2016). What does policy-relevant global environmental knowledge do? The cases of climate and biodiversity. Curr. Opin. Environ. Sustain. 18, 65-72. doi: 10.1016/j.cosust.2015.09.004

UN WomenWatch Women (2018). Gender Equality and Climate Change. Available online at: http://www.un.org/womenwatch/feature/climate_change/ downloads/Women_and_Climate_Change_Factsheet.pdf (Accessed Mar 10, 2018).

Van Asselt, H. (2016). The role of non-state actors in reviewing ambition, implementation, and compliance under the paris agreement. Clim. Law 6, 91-108. doi: 10.1163/18786561-00601006

Vogel, B., and Henstra, D. (2015). Studying local climate adaptation: a heuristic research framework for comparative policy analysis. Glob. Environ. Chang 31, 110-120. doi: 10.1016/j.gloenvcha.2015.01.001

Weisser, F., and Müller-Mahn, D. (2016). No place for the political: microgeographies of the paris climate conference 2015. Antipode 49, 802-820. doi: 10.1111/anti.12290

Whitmarsh, L., and Corner, A. (2017). Tools for a new climate conversation: a mixed-methods study of language for public engagement across the political spectrum. Glob. Environ. Chang 42, 122-135. doi: 10.1016/j.gloenvcha.2016.12.008

Whitmarsh, L., O'Neill, S., and Lorenzoni, I. (2010). Engaging the Public With Climate Change: Behaviour Change and Communication. London: Earthscan.

Conflict of Interest Statement: The authors declare that the research was conducted in the absence of any commercial or financial relationships that could be construed as a potential conflict of interest.

Copyright (c) 2019 Kythreotis, Mantyka-Pringle, Mercer, Whitmarsh, Corner, Paavola, Chambers, Miller and Castree. This is an open-access article distributed under the terms of the Creative Commons Attribution License (CC BY). The use, distribution or reproduction in other forums is permitted, provided the original author(s) and the copyright owner(s) are credited and that the original publication in this journal is cited, in accordance with accepted academic practice. No use, distribution or reproduction is permitted which does not comply with these terms. 